\title{
APA ITU PATEN DAN PATEN UNTUK CANON LENSA ZOOM
}

\section{wahyudi \\ 155100078}

Fakultas Komputer, GAGAL000

wahyudi.student@umitra.ac.id

\begin{abstract}
Kata paten (bahasa Inggris: patent), berasal dari kata patere yang berarti membuka diri untuk pemeriksaan publik, di Inggris istilah patent dikaitkan dengan surat keputusan yang dikeluarkan oleh pihak kerajaan yang memberikan hak eksklusif kepada individu (inventor) atau pelaku bisnis tertentu.

Sementara menurut undang-undang nomor 14 tahun 2001 tentang Paten, Paten didefinisikan sebagai hak eksklusif yang diberikan oleh Negara kepada Inventor terhadap hasil Invensinya di bidang teknologi, yang untuk selama waktu tertentu melaksanakan sendiri Invensinya tersebut atau memberikan persetujuannya kepada pihak lain untuk melaksanakan invensi tersebut (UU 14 tahun 2001, ps. 1, ay. 1).

Secara umum, Hal-hal atau subjek yang dapat dipatenkan antaralain, yaitu:

Proses, mesin, dan barang yang diproduksi dan digunakan. (Proses mencakup algoritma, Mesin mencakup alat dan aparatus. Barang yang diproduksi mencakup perangkat mekanik, perangkat elektronik dan komposisi materi seperti kimia, obatobatan, DNA, RNA, dan sebagainya), Metode bisnis, Sebagian besar perangkat lunak, Teknik medis (kedokteran), Teknik olahraga dan sejenisnya.
\end{abstract}

Salah satu produk dari Nikon, yang sudah dipatenkan yaitu desain lensa $7.4-600 \mathrm{~mm}$ $\mathrm{f} / 2,8-6,3$ dan khusus dirancang untuk kamera dengan sensor 1" (setara 20-1620mm $\mathrm{f} / 2,8-6,3)$.

Kata Kunci : Paten, Inventor, Nikon, dan Desain Lensa 


\section{A. INTRODUCTION}

Istilah "paten" sering kita dengar banyak dipakai oleh masyarakat luas dan bahkan tak jarang disalah-pahami sebagai padanan dari istilah "hak kekayaan intelektual" itu sendiri. Namun sesungguhnya, paten hanyalah salah-satu dari sekian banyak bentuk perlindungan HKI.

Paten adalah perlindungan HKI bagi karya intelektual yang bersifat teknologi, atau dikenal juga dengan istilah invensi, dan mengandung pemecahan/solusi teknis terhadap masalah yang terdapat pada teknologi yang telah ada sebelumnya.

Kata paten (bahasa Inggris: patent), berasal dari kata patere yang berarti membuka diri untuk pemeriksaan publik, di Inggris istilah patent dikaitkan dengan surat keputusan yang dikeluarkan oleh pihak kerajaan yang memberikan hak eksklusif kepada individu (inventor) atau pelaku bisnis tertentu.
Sementara menurut undang-undang nomor 14 tahun 2001 tentang Paten, Paten didefinisikan sebagai hak eksklusif yang diberikan oleh Negara kepada Inventor terhadap hasil Invensinya di bidang teknologi, yang untuk selama waktu tertentu melaksanakan sendiri Invensinya tersebut atau memberikan persetujuannya kepada pihak lain untuk melaksanakan invensi tersebut (UU 14 tahun 2001, ps. 1, ay. 1).

Dari definisi kata paten itu sendiri, konsep paten mendorong inventor untuk membuka pengetahuan demi kemajuan masyarakat dan sebagai gantinya, inventor mendapat hak eksklusif selama periode tertentu. Mengingat pemberian paten tidak mengatur siapa yang harus melakukan invensi yang dipatenkan, sistem paten tidak dianggap sebagai hak monopoli. Arti Invensi dan Inventor (yang terdapat dalam pengertian di atas, juga menurut undang-undang tersebut, adalah): 
a. Invensi adalah ide Inventor yang dituangkan ke dalam suatu kegiatan pemecahan masalah yang spesifik di bidang teknologi dapat berupa produk atau proses, atau penyempurnaandan

pengembangan produk atau proses. (UU RI no. 14 tahun 2001, ps. 1, ay. 2)

b. Inventor adalah seorang yang secara sendiri atau beberapa orang yangsecarabersama-sama melaksanakan ide yang dituangkan ke dalam kegiatan yang menghasilkan Invensi. (UU RI no. 14 tahun 2001, ps. 1, ay. 3)

Secara umum, Hal-hal atau subjek yang dapat dipatenkan adalah:

1. Proses, mesin, dan barang yang diproduksi dan digunakan. Proses mencakup algoritma, Mesin mencakup alat dan aparatus.

Barang yang diproduksi mencakup perangkat mekanik, perangkat elektronik dan komposisi materi seperti kimia, obat-obatan, DNA, RNA, dan sebagainya.

2. Metode bisnis,
3. Sebagian besar perangkat lunak

4. Teknik medis (kedokteran),

5. Teknik olahraga dan sejenisnya.

Hal-hal yang tidak dapat atau masih bersifat kontroversial untuk dipatenkan baik di Negara lain maupun di Indonesia antara lain:

1. Rumus-rumus atau kebenaran matematika,

2. Perangkat lunak yang menerapkan algoritma kecuali perangkat lunak tersebut memiliki aplikasi praktis (di Amerika Serikat perangkat lunak semacam itu dapat dipatenkan) atau memiliki efek teknikal (di Eropa dapat dipatenkan). Saat ini, masalah paten perangkat lunak dan juga metode bisnis masih merupakan subjek yang sangat kontroversial. Amerika Serikat dalam beberapa kasus hukum di sana, mengijinkan paten untuk perangkat lunak dan metode bisnis, sementara di Eropa, perangkat lunak dianggap tidak boleh dipatenkan, meskipun beberapa invensi yang menggunakan perangkat lunak masih tetap dapat dipatenkan. 
3. Paten yang berhubungan dengan zat-zat alamiah, misalnya zat yang ditemukan di hutan rimba dan juga obat-obatan, teknik penanganan kedokteran atau medis dan juga sekuens genetik, termasuk juga subjek yang masih bersifat kontroversial untuk dapat dipatenkan. Di berbagai negara, terdapat perbedaan dalam menangani subjek yang berkaitan dengan hal ini. Misalnya, di Amerika Serikat, metode bedah dapat dipatenkan, namun hak paten ini secara praktis masih sulit untuk diwujudkan.

4. Prosesatauprodukyang

pelaksanaannya bertentangan dengan undang-undang, moralitas, agama, ketentraman dan ketertiban umum atau kesusilaan; metode pemeriksaan, perawatan, pengobatan dan/atau pembedahan yang diterapkan terhadap manusia dan/atau hewan; serta teori dan metode di bidang matematika dan ilmu pengetahuan, yakni semua makhluk hidup, kecuali jasad renik, dan proses biologis penting untuk produksi tanaman atau hewan, kecuali proses nonbiologis atau proses mikrobiologis.

5. Teknologi tepat guna

Di Indonesia, syarat hasil temuan yang dapat dipatenkan antara lain:

1. Invensi memiliki aspek kebaruan, atau dengan kata lain invensi itu belum pernah diungkapkan sebelumnya.

2. Invensiharusmengandung langkah inventif, yaitu mengandung langkah yang tidak diduga sebelumnya bagi seseorang dengan keahlian tertentu di bidang teknik.

3. Invensi dapat diterapkan dalam industri.

Untuk memastikan teknologi yang diteliti belum dipatenkan oleh pihak lain dan layak dipatenkan, dapat dilakukan penelusuran dokumen paten melalui penelusuran internet atau ke kantor paten.

Pemberian hak paten bersifat teritorial, yaitu, mengikat hanya dalam lokasi tertentu. Dengan demikian, untuk mendapatkan perlindungan paten di beberapa negara atau wilayah, 
seseorang harus mengajukan aplikasi paten di masing-masing negara atau wilayah tersebut.

Salah satu contoh produk Nikon yang sudah dipatenkan yaitu desain lensa 7.4600mm f/2,8-6,3 dan khusus dirancang untuk kamera dengan sensor 1" (setara 20-1620mm f/2,8-6,3).

Dengan lensa tersebut tepatnya akan memiliki optical zoom sebesar 81x, meski digambarkan $75 x$ zoom pada paten. Mungkin ini akan menjadi kamera super-zoom baru mirip dengan Coolpix P900 (zoom 65x), tetapi dengan sensor 1". Dalam 2 tahun terakhir Canon telah mengajukan beberapa paten untuk lensa yang khusus dirancang untuk sensor 1".

Berikut adalah rincian patennya :

1. Paten: 2016-156901

2. Ditampilkan di 1 September 2016

3. Diajukan pada 24 Februari 2015

4. Rasio zoom: $75.5 \mathrm{x}$

5. f: $7.70-67,58-581,59$ (focal length)

6. Fno: 2,75-5,02-6,44 (aperture)

7. $2 \omega 92,5813,4461,5466$ (sudut pandang)

8. BF: $1.00-1,00-1,00$ (backfocus)
9. TL: $210,44-273,47-321,86$ (panjang total lensa)

10. Fokus dalam (antara group 4 dan 5)

11. Vibration Reduction (group 3)

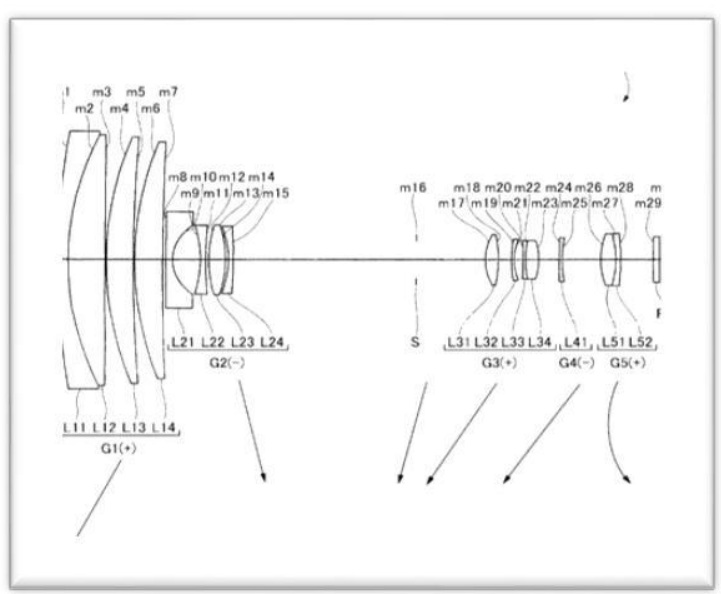

Gambar 01. Paten Canon Lensa Zoom $75 \mathrm{x}$

\section{B. CONCLUSION}

Kata paten (bahasa Inggris: patent), berasal dari kata patere yang berarti membuka diri untuk pemeriksaan publik, di Inggris istilah patent dikaitkan dengan surat keputusan yang dikeluarkan oleh pihak kerajaan yang memberikan hak eksklusif kepada individu (inventor) atau pelaku bisnis tertentu.

Sementara menurut undang-undang nomor 14 tahun 2001 tentang Paten, Paten didefinisikan sebagai hak 
eksklusif yang diberikan oleh Negara kepada Inventor terhadap hasil Invensinya di bidang teknologi, yang untuk selama waktu tertentu melaksanakan sendiri Invensinya tersebut atau memberikan persetujuannya kepada pihak lain untuk melaksanakan invensi tersebut (UU 14 tahun 2001, ps. 1, ay. 1).

Secara umum, Hal-hal atau subjek yang dapat dipatenkan antaralain, yaitu: Proses, mesin, dan barang yang diproduksi dan digunakan. (Proses mencakup algoritma, Mesin mencakup alat dan aparatus. Barang yang

diproduksi mencakup perangkat mekanik, perangkat elektronik dan komposisi materi seperti kimia, obatobatan, DNA, RNA, dan sebagainya), Metode bisnis, Sebagian besar perangkat lunak, Teknik medis (kedokteran), Teknik olahraga dan sejenisnya.

Salah satu produk dari Canon, yang sudah dipatenkan yaitu desain lensa 7.4-600mm f/2,8-6,3 dan khusus dirancang untuk kamera dengan sensor 1" (setara 20-1620mm f/2,8-6,3).

Berikut adalah rincian patennya :
1. Paten: 2016-156901

2. Ditampilkan di 1 September 2016

3. Diajukan pada 24 Februari 2015

4. Rasio zoom: $75.5 \mathrm{x}$

5. f: $7.70-67,58-581,59$ (focal length)

6. Fno: 2,75-5,02-6,44 (aperture)

7. $2 \omega 92,5813,4461,5466$ (sudut pandang)

8. BF: $1.00-1,00-1,00$ (backfocus)

9. TL: $210,44-273,47-321,86$ (panjang total lensa)

10. Fokus dalam (antara group 4 dan 5)

11. Vibration Reduction (group 3)
C. ACKNOWLEDGEMENT University Of Indonesia University Of Mitra Indonesia Telkom University University Of Mellbourne Saitama University

\section{REFERENCE $($ Based ISo 690 )}

[1] A. S. Putra And O. M. Febriani, "KnowledgeManagement Online Application In Pdam LampungProvince,'In Prosiding International Conference On Information Technology And Business (Icitb), 2018, Pp. 181-187.

[2] A. S. Putra, O. M. Febriani, And B.Bachry,"Implementasi 
Genetic Fuzzy System Untuk Mengidentifikasi Hasil Curian Kendaraan Bermotor Di Polda Lampung," J. Sist. Inf. Dan Manaj. Basis Data, Vol. 1, No. 1, Pp. 21-30, 2018.

[3] O. M. Febriani And A. S. Putra, "Sistem Informasi Monitoring Inventori Barang Pada Balai Riset Standardisasi Industri Bandar Lampung," J. Inform., Vol. 13, No. 1, Pp. 90-98, 2014.

[4] Putra, Arie Setya. "2018 Artikel Struktur Data, Audit Dan Jaringan Komputer." (2018).

[5] Putra, A. S. (2018, July 17). Paperplain Fundamental Create Application With Borland Delphi 7.0 University Of Mitra Indonesia. Retrieved From Osf.Io/Pbrn9.

\section{E. REFERENCE (Based APA )}

Putra, A. S., Aryanti, D. R., \& Hartati, I. (2018, November). Metode SAW (Simple Additive Weighting) sebagai Sistem Pendukung Keputusan Guru Berprestasi (Studi Kasus: SMK Global Surya). In Prosiding Seminar Nasional Darmajaya (Vol. 1, No. 1, pp. 85-97).

Sari, D. P., Febriani, O. M., \& Putra, A. S. (2018, November). Perancangan Sistem Informasi SDM Berprestasi pada SD Global Surya. In Prosiding Seminar Nasional Darmajaya (Vol. 1, No. 1, pp. 289-294).

Putra, A. S. (2018). Paperplain: Execution Fundamental Create Application With Borland Delphi 7.0 University Of Mitra Indonesia.
Putra, A. S., Sukri, H., \& Zuhri, K. Sistem Monitoring Realtime Jaringan Irigasi Desa (JIDES) Dengan Konsep Jaringan Sensor Nirkabel. IJEIS (Indonesian Journal of Electronics and Instrumentation Systems), 8(2), 221232.

Darmawan, A., Yuliawati, D., Marcella, O., \& Firmandala, R. (2016). Sistem Absensi dan Pelaporan Berbasis Fingerprint dan SMS Gateway. EXPLORE, 7(1).

Febriani, O. M., Wahyuni, T., \& Yusuf, S. (2017). DESIGN OF WEBSITE-BASED INFORMATION SYSTEM FOR EDOCUMENT ADMINISTRASI IN THE COMMUNITY SERVICE UNIT (A Case Study at Rajabasa District).

INTERNATIONAL JOURNAL OF COMPUTERS \& TECHNOLOGY, 16(7), 7010-7020.

Febriani, O. M., \& Wahyuni, T. (2017, October). PERANCANGAN SISTEM E-DOCUMENT ADMINISTRASI LOGBOOK PENELITIAN PADA UNIT LAYANAN DI BANDAR LAMPUNG. In Prosiding Seminar Nasional Darmajaya (Vol. 1, No. 1, pp. 187-194).

Febriani, O. M., \& Permadi, A. B. (2017). Implementasi Sistem Aplikasi Data Bimbingan dan Pelanggaran Siswa pada Sekolah Menengah Atas di Lampung Tengah dengan Metode Analisis dan Desain Sistem Terdistribusi (SSAD). EXPERT, 7(1).

Febriani, O. M., \& Ambarwati, L. (2015). PERANCANGAN APLIKASI 
Fakultas Komputer

wahyudi

Section Class Content

PENGOLAHAN

DATA

PENJUALAN UKM KELANTING

KHAS TELO DESA SIDOHARJO

KECAMATAN JATI AGUNG

KABUPATEN LAMPUNG

SELATAN. Jurnal Teknologi

Informasi dan Bisnis Pengabdian

Masyarakat Darmajaya, 1(1), 77-95.

Febriani, O. M. (2015). Rancang

Bangun Aplikasi E-

commercemenggunakan Freewebstore

pada UKM Kelanting di Desa

Sidoharjo Lampung Selatan. Prosiding

Sembistek 2014, 1(02), 446-458. 